\title{
KARAKTERISTIK MUTU MINYAK KELAPA TRADISIONAL PADA UKM SUKSES BERSAMA DENGAN METODE FERMENTASI
}

\author{
Rosdiani Azis ${ }^{1)}$, Moh. Fikri Pomalingo ${ }^{2)}$, Ingka Rizkyani Akolo \\ ${ }^{1}$ Program Studi Teknologi Hasil Pertanian, Politeknik Gorontalo \\ ${ }^{2}$ Program Studi Teknik Mesin, Universitas Negeri Manado \\ Email: rosdiani@poligon.ac.id ${ }^{1)}$
}

\begin{abstract}
ABSTRAK
UKM Sukses Bersama adalah merupakan salah satu UKM yang bergerak dalam pengolahan kelapa menjadi minyak kelapa tradisional, Kelapa merupakan komoditas yang tersebar diseluruh Indonesia namun konsumsi minyak yang berasal dari kelapa masih sangat kurang. Minyak kelapa yang di hasilkan pada umumnya berkualitas rendah (cepat tengik), selain itu minyak yang di hasilkan warna yang keruh dan beraroma yang khas (aroma blondo), hal ini disebabkan oleh proses pengolahan minyak yang kurang baik dan waktu pengolahan yang relatif lama yang mana sering di keluhkan masyarakat, oleh karena itu perlu metode Fermentasi sebagai solusi pengolahan minyak kelapa tradisional yang lebih efektif dan efisien. Analisis data dilakukan dengan metode deskriptif. Penelitian ini bertujuan untuk mengetahui mutu minyak kelapa yang di hasilkan dari UKM SUKSES BERSAMA. Parameter yang diukur dalam penelitian ini adalah bilangan peroksida, bilangan asam lemak bebas, bilangan penyabunan, bilangan Iod serta sifat organoleptik yang meliputi warna dan aroma. Hasil penelitian memperlihatkan bahwa minyak hasil fermentasi dari UKM ini memenuhi Standar Nasional Indonesia yakni Bilangan Iod 8,14 mg jod/100g, Bilangan peroksida Nil mg oksigen/g, Bilangan penyabunan $264.37 \mathrm{mg} \mathrm{KOH} / \mathrm{g}$ dan Asam lemak bebas $0,17 \%$ dan warna maupun aroma normal.
\end{abstract}

Kata kunci: UKM, Kelapa, Minyak Kelapa, Fermentasi, asam lemak

\section{ABSTRACT}

Sukses Bersama SMEs is one of the Small Medium Enterprises (SMEs) that is involved in processing coconut into traditional coconut oil. Coconut is a commodity that is spread throughout Indonesia but consumption of oil derived from coconuts is still very lacking. Coconut oil produced is generally of low quality (fast rancid), in addition to oil produced in a turbid color and has a distinctive aroma (blondo aroma). This is caused by poor oil processing and relatively long processing times which are often where being complained by the people. Therefore it is necessary to use the fermentation method as a solution for traditional coconut oil processing which is more effective and efficient. Data analysis was performed using descriptive methods. This study aims to determine the quality of coconut oil produced from Sukses Bersama SMEs. The parameters measured in this study are peroxide numbers, free fatty acid numbers, saponification numbers, Iodic numbers and organoleptic properties which include color and aroma. The results showed that fermented oil from SMEs fulfilled the Indonesian National Standards namely Iod Numbers $8.14 \mathrm{mg}$ jod / 100g, Nil peroxide Numbers mg oxygen / g, Oxygenation Numbers $264.37 \mathrm{mg} \mathrm{KOH} / \mathrm{g}$ and Free fatty acids $0.17 \%$ and color as well as normal scents.

\section{Keywords: SMES, coconut, Coconut Oil, Fermentation, Fatty Acid}

\section{PENDAHULUAN}

Kelapa (Cocos nucifera L.) merupakan salah satu tanaman perkebunan yang paling banyak dibudidayakan di Provinsi Gorontalo. Berdasarkan data yang dilaporkan oleh Badan Pusat Statistik (BPS) Provinsi Gorontalo. Tanaman ini tersebar di 4 kabupaten yakni kabupaten Gorontalo 22.810 hektar, kabupaten Pohuwato 14.312 hektar, kabupaten Gorontalo Utara 8528 hektar, dan kabupaten Boalemo 6862 hektar. Produksi buah kelapa selama 7 tahun terakhir (2010-2016) juga cukup besar yakni berkisar antara 54.000 ton sampai 67.000 ton pertahun (BPS,2016). Budidaya dan pengolahan kelapa di Gorontalo tergolong masih sangat tradisional. Hal itu terlihat dari peralatan yang digunakan oleh petani. Pemanenan kelapa masih dilakukan dengan cara memanjat pohon, pengupasan sabut masih menggunakan luweng (pasundi), dan pembelahan buah kelapa yang masih menggunakan parang

Minyak kelapa mengandung asam lemak jenuh $92 \%$, jika minyak kelapa digunakan untuk rnenggoreng, struktur kimianya tidak berubah, karena 92 jenis asam lemaknya sudah dalam bentuk lemak jenuh jadi tetap stabil. Selain itu, minyak kelapa adalah satu-satunya minyak goreng yang mengandung asam laurat (lauric acid) 47,5\% dengar 
kadar setara dengan asam tartarat pada air susu ibu (kurang dari 50\%). Hasil proses pencernaan dan metabolisme minyak menghasilkan energi tinggi, tetapi jika di bandingkan energi yang di hasilkan, minyak kelapa jauh lebih tinggi dari pada minyak kelapa sawit.

Industri rumah tangga mengolah kelapa menjadi minyak, tetapi kualitas dan kuantitasnya masih rendah; Selain itu masalah yang sering dikeluhkan masyarakat adalah bahwa dalam pengolahan minyak dipasaran membutuhkan waktu yang relatif lama dan minyak kelapa yang dihasilkanpun mudah tengik sehingga perlu mencari metode yang efektif dan efisien agar minyak yang dihasilkan memtftki kualitas dan kuantitas yang baik.

Pada penelitian ini telah dilakukan pembuatan minyak kelapa dengan menggunakan metode fermentasi, metode ini memisahkan krim dan whey dengan cara fermentasi santan. Metode ini merupakan salah satu metode efektif yang di aplikasikan oleh UKM sukses bersama UKM ini pernah mengaplikasikan metode pemasakan namun waktu yang digunkan cenderung lebih lama dan kualitas minyak juga kurang berkualitas hal ini dilihat dari daya simpan dan kejernihan minyak.

Minyak kelapa yang dihasilkan oleh UKM pada umumnya berkualitas rendah (cepat tengik) hal ini disebabkan proses pemasakan yang tidak maksimal dan masih terdapat komponen-komponen yang bersifat merugikan (kandungan air, pigmen dan asam - lemak bebas seperti monogliserida, digliserida dan turunan dari lemak lainnya) sehingga berpengaruh terhadap kualitas minyak yang dihasilkan, selain itu minyak yang dihasilkan warna yang tidak jernih dan beraroma yang khas (aroma blondo), sedangkan saat ini masyarakat menginginkan minyak yang jernih dan aroma minyak yang tidak berbau khas dari blondo. Sehingga UKM Sukses Bersama memproduksi minyak dengan menggunakan metode fermentasi dan untuk mengetahui kualitas minyak maka dilakukan analisis kandungan minyak sampai menyentuh asam lemak yang dimiliki minyak.

Penelitian ini bertujuan untuk mengetahui mutu minyak kelapa dengan mempelajari pengaruh Fermentasi terhadap mutu minyak yang di hasilkan UKM Sukses Bersama. Penelitian ini berguna sebagai rujukan dan altematif pengolahan yang di gunakan daiam industri rumah tangga ataupun UKM lainnya untuk menggunakan metode yang fermentasi dalam pengelolaan minyak agar mendapatkan keuntungan jika dilihat dari kualitas dan kuantitas.

\section{METODELOGI PENELITIAN}

\subsection{Waktu dan Tempat}

Penelitian ini dilaksanakan pada bulan Juni Agustus 2019, di rumah produksi UKM Sukses
Bersama. Pengujian komposisi kimia minyak kelapa yang diproduksi oleh UKM dilakukan di Laboratorium Sucofindo, Bekasi.

\subsection{Alat dan Bahan}

\subsubsection{Alat}

Alat-alat yang digunakan untuk pembuatan minyak adalah timbangan, kasar, baskom, kompor, wajan, pengaduk, wadah fermentasi berupa plastik, kertas saring. Alat-alat yang digunakan pada penelitian ini adalah erlemeyer, oven, biuret, desikator, timbangan analitik, batang pengaduk.

\subsubsection{Bahan}

Bahan-bahan yang digunakan pada pembuatan minyak kelapa ini adalah kelapa tua jenis kelapa dalam yang telah diparut dan air hangat, Bahan-bahan yang digunakan untuk analisa fisikokimia aquades, alkohol netral, larutan jenuh $\mathrm{Kl}$, $\mathrm{NaOH}, \mathrm{Na}_{2} \mathrm{~S}_{2} \mathrm{O}_{3}$, asam asetat glasial, kloroform, indicator, larutan pati $1 \%$ dan phenolphtalin.

\subsection{Prosedur Penelitian}

Adapun prosedur penelitian diawali dengan pemeraman dan pemasakan santan yang menghasilkan minyak.

Pembuatan minyak kelapa dengan pemeraman dan pemanasan:

1 Delapan puluh buah kelapa tua dikupas sabutnya kemudian dipisahkan dari daging buah, air dan tempurung.

2 Daging buah kelapa dicuci, ditiriskan dan diparut,

3 Hasil parutan ditambahkan dengan air hangat dengan perbandingan 1:2,

4 Proses pemerasan dengan cara dipres dengan dongkrak dilakukan sebanyak 2 kali, penambahan air hangat dilakukan untuk mempermudah pemerasan kelapa parut.

5 Santan yang dihasilkan peruntuhkan untuk pengolahan minyak dengan fermentasi:

6 Perlakuan ini dilakukan fermetasi santan pada wadah fermentasi selama 6 jam, sampai terjadi perubahan yakni air menjadi bening dan tidak menimbulkan aroma asam sehingga didapatkan pemisahan whey dan krim

7 Krim tersebut kemudian masing-masing dipanaskan pada suhu sekitar $102{ }^{\circ} \mathrm{C}$ sampai diperoleh perubahan dengan wama minyak bening dan warna blondo masih putih dengan waktu kurang dari 1 jam.

\subsection{Analisis Data Penelitian}

Perlakuan yang digunakan pada penelitian ini terdiri atas 2 Sampel dan 3 kali Ulangan yakni:

A = Minyak kelapa tanpa proses fermentasi

$\mathrm{B}=$ Minyak kelapa dengan proses fermentasi 
Parameter yang diamati dalam penelitian ini adalah asam lemak bebas (ALB), bilangan peroksida, dan uji Organoleptik terhadap warna dan aroma. Uji asam lemak bebas (ALB), dan bilangan peroksida, dilakukan pada perlakuan $\mathrm{B}$, sedangkan uji organoleptik dilakukan dengan membandingkan antara sampel A dan B. Analisis data dilakukan dengan metode deskriptif.

\section{HASIL DAN PEMBAHASAN \\ 3.1. Uji Organoleptik Warna}

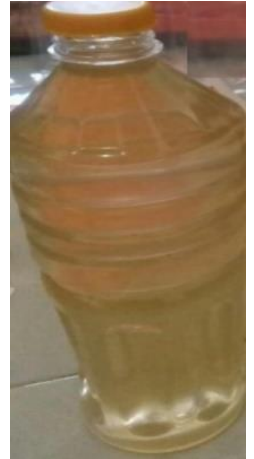

(a)

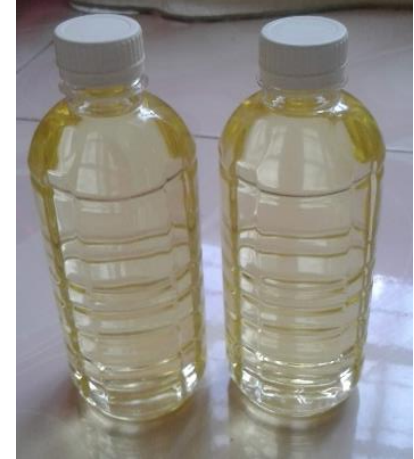

(b)
Gambar 1. (a) Minyak kelapa tanpa fermentasi, dan (b) Minyak kelapa dengan fermentasi

Warna minyak kelapa tradisional dengan metode fermentasi menunjukkan warna normal yakni kuning dan terlihat jernih. Adanya warna tersebut dipengaruhi karena bahan dasar yang digunakan dan suhu selama pengolahan. Adapun daging kelapa yang mengandung protein dan karbohidrat diolah dengan suhu pengolahan yang tinggi $\left(>100^{\circ} \mathrm{C}\right)$ dan pemanasan yang lama (+ 1 jam $)$ akan menghasilkan warna kuning bening pada minyak kelapa. Penelitian ini menunjukkan bahwa warna minyak kelapa tradisional dengan pengolahan metode fermentasi yakni bening jernih karena menggunakan suhu pemanasan yang konsisten atau suhu tetap dipertahankan sekitar $95-100^{\circ} \mathrm{C}$ dan proses pemanasan lebih cepat (sekitar 1 jam), karena dengan proses fermentasi santan dilakukan pemisahan skim, krim dan air, dan yang dipanaskan hanya krim dan skim saja sehingga proses pemanasan lebih cepat karena air yang ada pada minyak dipisahkan dan dibuang, sedangkan warna yang dimiliki oleh perlakuan minyak tradisional tanpa fermentasi warnanya lebih pada kuning kecoklatan hal ini karena proses pemanasan yang terlalu lama pada minyak menyebabkan warna lebih kuning dan juga karena perlakuan pemanasan menyebabkan warna terlihat keruh karena kandungan air saat proses pengolahan minyak lebih banyak sehingga berpengaruh pada kualitas warna minyak.

\subsection{Uji Organoleptik Aroma}

Berdasarkan hasil uji organoleptik menunjukkan bahwa aroma minyak kelapa hasil fermentasi dinilai normal dan sesuai dengan standar SNI. Adapun aroma/bau minyak kelapa tradisional dengan metode pengolahan fermentasi menunjukkan aroma khas minyak khas blondo atau normal dan tidak memiliki bau asam. Hal ini, disebabkan karena adanya proses fermentasi sehingga berpengaruh pada minyak yang dihasilkan. Selain itu, minyak yang dihasilkan dilakukan proses penyaringan dengan kertas saring sehingga menghasilkan minyak tanpa endapan. Sedangka aroma minyak kelapa tanpa fermentasi memiliki aroma yang berbeda yakni beraroma arang akibat pemanasan yang terlalu lama sehingga berpengaruh pada kualitas aroma minyak yang dihasilkan. Hal ini dipengaruhi karena proses pemanasan yang terlalu lama kurang lebih 12 jam sehingga aroma yang dihasilkan kurang menarik sehingga ini dapat membuat minyak cepat mengalami ketengikan.

\subsection{Deskriptif Hasil Pengujian Komposisi Kimia Minyak Kelapa}

Hasil pengujian komposisi kimia minyak kelapa yang dilakukan di Laboratorium Sucofindo Bekasi ditampilkan pada Tabel 1.

Tabel 1. Hasil pengujian komposisi kimia minyak kelapa tradisional

\begin{tabular}{cc}
\hline Karakteristik & Hasil Uji \\
\hline Asam Lemak Bebas & $0,17 \%$ \\
Bilangan Peroksida (mg oksigen/g) & Nil \\
Bilangan Penyabunan (mg KOH/g) & 264,37 \\
Bilangan Iod & 8,41 \\
\hline
\end{tabular}

Pembahasan untuk masing-masing karakteristik hasil pengujian akan dibahas pada sub-bab selanjutnya.

\subsubsection{Asam Lemak Bebas}

Asam lemak bebas pada pengujian minyak kelapa ini adalah 0,17\% sementara syarat mutu SNI minyak kelapa untuk asam lemak bebas adalah 0,2 $\%$. Hal ini menunjukkan bahwa minyak ini masih memenuhi syarat SNI. Asam lemak bebas pada minyak kelapa merupakan salah satu indikasi kerusakan pada minyak, semakin tinggi asam lemak bebasnya maka semakin tinggi pula peluang terjadinya kerusakan pada minyak. Adanya asam 
lemak bebas pada minyak hasil fermentasi disebabkan karena metode fermentasi meminimalkan kandungan air dan proses pemanasan karena pemanasan memicu yang memicu kerusakan pada minyak hal ini sesuai dengan penelitian Alamsyah (2007) bahwa keberadaan asam lemak bebas biasanya dijadikan indikator awal terjadinya kerusakan minyak. Penelitian Ida Bagus dkk (2013) menyatakan bahwa pada penelitian tersebut menunjukkan bahwa asama lemak bebas dimiliki oleh minyak kelapada hasil fermentasi rahi tempe menunjukkan bahwa bahwa bilangan asam maksimal untuk minyak goreng adalah 2 mg KOH/g, 70 maka hasil penetapan kadar bilangan asam menunjukkan bahwa minyak dari setiap perlakuan tersebut mempunyai angka asam di bawah standar yang telah ditetapkan dan menunjukkan bahwa kualitas dari minyak tersebut baik dan hal ini membuktikan bahwa metode fermntasi efektif dalam proses pengolahan minyak tradisional.

\subsubsection{Bilangan Peroksida}

Hasil bilangan peroksida minyak kelapa ini menunjukkan nilai nol artinya tidak terindikasi adanya peroksida, berdasarkan SNI angka peroksida minyak kelapa adalah maksimal 0,2 mg oksigen/g contoh, dari data di atas menunujukkan bahwa minyak kelapa tersebut tidak terindikasi adanya ketengikan karena angka peroksida dalam minyak kelapa menunjukkan bahwa semakin tinggi angka peroksida maka akan lebih besar peluangnya minyak ada teroksidasi, jika terjadi oksidasi pada minyak maka akan menyebabkan cepatnya minyak mengalami ketengikan. Pada produk minyak kelapa ini lebih kecil dari SNI. Hal ini berarti minyak kelapa ini telah memenuhi persyaratan mutu yang ditetapkan SNI dan minyak ini belum teroksidasi. Bilangan peroksida pada produk minyak Hasil fermentasi ini tidak terindikasi diduga disebabkan karena proses pengolahan fermentasi meminimalkan kontak dengan udara, sehingga proses oksidasi pada minyak belum terjadi. Hal tersebut di atas sesuai dengan pendapat Aziz (2018) bahwa kerusakan oksidasi berlangsung apabila terjadi kontak antara sejumlah oksigen, aktivitas phenol, penyerapan aroma, dan aktivitas mikroorganisme sehingga menyebabkan meningkatnya peroksida dengan ikatan rangkap pada minyak atau lemak. Senyawa peroksida merupakan produk yang terbentuk pada awal proses oksidasi yang sifatnya tidak stabil dan mudah terdekomposisi sehingga minyak hasil fermentasi berdasarkan data tersebut menunujukkan bahwa minyak kelapa tersebut tidak terindikasi adanya ketengikan karena angka peroksida dalam minyak kelapa menunjukkan bahwa semakin tinggi angka peroksida maka akan lebih besar peluangnya minyak ada teroksidasi, jika terjadi oksidasi pada minyak maka akan menyebabkan cepatnya minyak mengalami ketengikan.

Menurut Patty (2015), nilai kandungan peroksida dari penelitian yang dilakukan dapat diketahui bahwa angka peroksida yang paling rendah terdapat pada lama fermentasi 6 jam yaitu $0,0988 \%$, data ini menunjukkan bahwa nilainya masih memenuhi SNI dan berarti bahwa metode fermentasi begitu efektif digunakan dalam pengolahan minyak kelapa tradisional.

\subsubsection{Bilangan Penyabunan}

Bilangan penyabunan minyak kelapa ini $264.37 \mathrm{mg} \mathrm{KOH} / \mathrm{g}$ contoh, sementara standar minyak kelapa untuk bilangan penyabunan bersarkan SNI 255-265 KOH/g contoh, hal ini menunjukkan bahwa bilangan penyabunan pada produk ini masih sesuai dengan SNI. Bilangan penyabunan menjadi indikasi kekeruhan pada produk, jika melebihi standar mutu SNI berarti menunjukkan bahwa produk tersebut keruh. Pada produk minyak ini masih sesuai standar Mutu SNI. Adanya bilangan penyabunan pada minyak hasil fermentasi disebebkan karena karena banyaknya kandungan asam lemak laurat $45 \%$ dan asam lemak miristat $20 \%$ yang terkandung produk minyak. Besarnya bilangan penyabunan bergantung dari massa molekul minyak Hal ini sesuai dengan pendapat Sukandar dkk (2009) bahwa minyak yang memiliki berat molekul rendah akan mempunyai bilangan penyabunan yang lebih tinggi. Laurat termasuk ke dalam asam lemak rantai sedang dan menyebabkan massa molekul kecil sehingga bilangan penyabunannya tinggi. Hal ini diduga erat kaitannya dengan kandungan asam lemak dari minyak kelapa tradisional metode fermentasi yang terdiri dari $95 \%$ berupa asam lemak rantai sedang. Hal yang sama juga di ungkapkan oleh Ketaren (1986), bahwa angka penyabunan dalam minyak dipengaruhi oleh adanya senyawa yang tak tersabunkan dalam minyak seperti sterol, pigmen, hidrokarbon, dan tokoferol yang dapat mengurangi kekuatan oksidasi terhadap ikatan tidak jenuh asam lemak. Karena bilangan penyabunan memiliki nilai yang relativ sama, berarti minyak hasil fermentasi 
tersusun dari trigliserida dengan berat molekul yang relatif sama.

\subsubsection{Bilangan Iod}

Hasil uji laboratorium menunjukkan bahwa untuk minyak kelapa tradisional dengan metode pengolahan metode fermentasi menunjukkan bilangan Iod nilainya $8.41 \mathrm{mg}$ jod/100 g contoh. Sementara untuk SNI minyak kelapa bilangan iodnya 4-11 mg jod/100 g. Hal ini menunjukkan bahwa bilangan iodnya relatif masih rendah dan memenuhi SNI. Hal ini dikarenakan ada banyak komponen asam lemak yang bersifat jenuh yang memiliki ikatan tunggal dan rendah/ sedikit asam lemak tak jenuh yang memiliki ikatan rangkap, sehingga menyebabkan jumlah bilangan iodnya relatif lebih rendah. Hasil ini sesuai dengan pendapat Sukandar dkk. (2009) bahwa semakin tinggi bilangan iod, maka semakin banyak ikatan rangkap pada asam lemak suatu produk minyak. Semakin tinggi ikatan rangkap dalam suatu minyak, maka potensi ketengikan pada minyak semakin besar, karena memiliki sifat yang mudah teroksidasi oksigen di udara, senyawa kimia lainnya atau proses pemanasan. Ketengikan ini diartikan sebagai kerusakan atau perubahan bau dan rasa (flavour) dalam minyak pada proses pembuatan minyak pada masih berada di angka yang sesuai dengan SNI. Hal ini berarti minyak kelapa ini telah memenuhi persyaratan mutu yang ditetapkan SNI.

\section{Kesimpulan dan Saran}

\subsection{Kesimpulan}

Kesimpulan yang diperoleh dari penelitian ini adalah berikut:

1. Minyak hasil produksi UKM Sukses Bersama telah memenuhi Standar SNI

2. Analisis kimia minyak tradisional dengan metode fermentasi adalah Bilangan Iod 8,14 $\mathrm{mg}$ jod/100g), bilangan peroksida Nil mg oksigen/g, bilangan penyabunan $264.37 \mathrm{mg}$ $\mathrm{KOH} / \mathrm{g}$ dan asam lemak bebas $0,17 \%$

3. Analisis fisik minyak kelapa tradisional produksi UKM Sukses Bersama adalah normal sesuai SNI.

\subsection{Saran:}

Untuk menghasilkan nilai ekonomi pada industri minyak maka perlu dilakukan perhitungan rendemen minyak.

\section{DAFTAR PUSTAKA}

Alamsyah, A.N. 2007. Virgin Coconut Oil Minyak Penakluk Aneka Penyakit. Jakarta: Penerbit Agromedia Pustaka
BPS. 2016. Provinsi Gorontalo dalam Angka Tahun 2016. Diakses dari www.gorontalo.bps.go.id. Tanggal 1 Maret 2019

Sukandar, D., Hermanto, S., dan Silvia, E. 2009. Sifat Fisiko Kimia Dan Aktivitas Antioksidan Minyak Kelapa Murni Rvcoi Hasil Fermentasi Rhizopus Orizae. Jkti, Vol. 11, No.2, Desember 2009

Ida Bagus Rai Wiadnya, Urip, Eka Minovriyanti, 2013. Pengaruh Penambahan Ragi Tempe (Rhizopus Sp) Pada Pembuatan Minyak Kelapa Terhadap Mutu Minyak. Politeknik Kesehatan Kemenkes Mataram Jurusan Analis Kesehatan

Ketaren, S. 2008. Pengantar Teknologi Minyak dan Lemak Pangan. Universitas Indonesia (UIPress). Jakarta

Patty, PV. Pengaruh Lama Fermentasi Terhadap Ranciditas Minyak Kelapa Yang Diproduksi Secara Tradisional. Biopendix, Volume 1, Nomor 2, Maret 2015, Hlm. 146-152

Azis, R. 2018. Karakterisasi Mutu Minyak Kelapa Hasil Proses Pemeraman Dan Pemasakan Santan, Journal Of Agritech Science (Jasc) Vol 2 No 1 (2018)

SNI 01 - 3555 -1998, Cara Uji Minyak Dan Lemak. Badan Standardisasi Nasional Gedung Manggala Wanabakti Blok Iv, Lt. 4 Ji. [End. Gatot Subroto, Senayan Jakarta 10270, E-Mail : Bsn@Bsn.Co.Id 